\title{
Effects of zinc and boron application on onion and their residual effects on Mungbean
}

\author{
R Begum ${ }^{1}$, M Jahiruddin ${ }^{*}$, MA Kader ${ }^{1}$, MA Haque ${ }^{2}$, ABMA Hoque ${ }^{3}$ \\ ${ }^{1}$ Department of Soil Science, ${ }^{3}$ Department of Environmental Science, Bangladesh Agricultural University, \\ Mymensingh-2202, Bangladesh; ${ }^{2}$ Department of Soil Science, Patuakhali Science \& Technology University, \\ Potuakhali, Bangladesh
}

\begin{abstract}
The effect of zinc (Zn) and boron (B) on the growth and yield of onion as well as their residual effect on mungbean were investigated in this study. The field experiment was conducted at Bangladesh Agricultural University Farm, Mymensingh. The soil was silt loam having $6.92 \mathrm{pH}, 2.82 \%$ organic matter, $0.63 \mu \mathrm{g} \mathrm{g}^{-1}$ available $\mathrm{Zn}$ and $0.27 \mu \mathrm{g} \mathrm{g}^{-1}$ available B contents. There were nine treatments comprising three rates of $\mathrm{Zn}(0,2$ and $4 \mathrm{~kg}$ $\left.\mathrm{ha}^{-1}\right)$ and three rates of $\mathrm{B}\left(0,1.5\right.$ and $\left.3 \mathrm{~kg} \mathrm{ha}^{-1}\right)$ in all combinations. The experiment was laid out in a randomized complete block design with three replications. $\mathrm{Zinc}$ as $\mathrm{ZnSO}_{4} \cdot 7 \mathrm{H}_{2} \mathrm{O}$ and boron as $\mathrm{H}_{3} \mathrm{BO}_{3}$ were applied to the first crop (onion cv. Faridpuri). Mungbean (cv. BINA Mung8) was grown on the same plots after harvesting of onion, with no further addition of $\mathrm{Zn}$ and B. For both crops, N, P, K and S fertilizers were added to the all plots as per recommendation (FRG-2012). Application of $\mathrm{Zn}$ and B significantly influenced the growth and yield parameters of crops viz. plant height, bulb diameter, bulb length and bulb yield for onion, and plant height, pods plant $^{-1}$, pod length, 1000-seed weight and seed yield for mungbean. Addition of $\mathrm{Zn}$ at $4 \mathrm{~kg} \mathrm{ha}^{-1}$ and B at $3 \mathrm{~kg} \mathrm{ha}^{-1}$ compared to control $\left(\mathrm{Zn}_{0} \mathrm{~B}_{0}\right)$ gave $52 \%$ yield benefits for onion and $99 \%$ yield benefits for mungbean. Zinc and $\mathrm{B}$ concentrations as well as their uptake by onion bulb were also positively influenced by the added $\mathrm{Zn}$ and $\mathrm{B}$. The results suggest that application of $\mathrm{Zn}$ at $4 \mathrm{~kg} \mathrm{ha}^{-1}$ coupled with B at $3 \mathrm{~kg} \mathrm{ha}^{-1}$ along with NPKS is required to achieve higher yield of onion and mungbean in Old Brahmaputra Floodplain (AEZ 9).
\end{abstract}

Key words: Zinc, boron, onion, mungbean, old brahmaputra floodplain

Progressive Agriculturists. All rights reserve

*Corresponding Author: m_jahiruddin@yahoo.com

\section{Introduction}

Onion (Allium cepa) among the spice crops occupies the first position in respect of production and the second position in respect of area in Bangladesh. Still, country's onion production is far below the requirement and to meet the demand the country is importing a huge quantity of onion mainly from India each year. After cultivation of winter onion, mungbean (Vigna radiata) as a grain legume is a good fit to crop calendar in Bangladesh. Mungbean is called poor man's meat since its seed contains almost triple amount of protein as compared to rice grain. It has a unique capacity to synthesize nitrogen in symbiosis with Rhizobium.

Increased cropping intensity along with cultivation of modern crop varieties having high yield potential has resulted in deterioration of soil fertility with an emergence of micronutrient deficiency in Bangladesh. Among the micronutrients, zinc and boron deficiencies have widely been reported (Hossain et al., 2008; Jahiruddin, 2011; Jahiruddin and Islam, 2014). Nevertheless, micronutrients have great roles in the fertilizer programme to achieve 
higher and sustainable crop yields. Micronutrients are also important for seed formation and seed quality (Jahiruddin et al., 1992; Cakmak et al., 1996; Ahmed et al., 2007). Boron deficiency may induce grain sterility in crops. Usually dicots have higher boron requirement than monocots.

Only four plant nutrients viz. N, P, K and S are commonly used by the farmers in Bangladesh. The importance of the use of micronutrients is mostly ignored although they could be chief limiting factor for crop production. However, micronutrient application needs a careful control. It is essential, but the amount of requirement is much less compared to macronutrient. Every crop application of micronutrient fertilizer may not be needed since its residual effect might be sufficient for achieving sustainable yield over a cropping pattern. There is a report that elevated concentration of boron would have toxic effect on crops (Metwally et al., 2012). Toxicity may arise in plants due to continuous application of micronutrients. Keeping the above points in view, the experiments were conducted at BAU farm, Mymensingh in Old Brahmaputra Floodplain soil with the objective of investigating the effects of $\mathrm{Zn}$ and $\mathrm{B}$ on onion and subsequently their residual effects on mungbean.

\section{Materials and Methods}

Two field experiments in sequence were conducted at BAU farm, Mymensingh in January -June 2013 with an objective of determining the effects of $\mathrm{Zn}$ and $\mathrm{B}$ on onion (cv. Faridpuri) and the residual effects on mungbean (cv. BINA mung 8). The BAU farm soil belongs to 'Sonatala' soil series under the AEZ 9 (Old Brahmaputra Floodplain). The soil was silt loam having $6.92 \mathrm{pH}, 2.82 \%$ organic matter, $0.63 \mu \mathrm{g} \mathrm{g}^{-1}$ available $\mathrm{Zn}$ and $0.27 \mathrm{\mu g} \mathrm{g}^{-1}$ available B contents. The experiment was designed with nine Zn-B treatments with three rates of $\mathrm{Zn}\left(0,2 \& 4 \mathrm{~kg} \mathrm{ha}^{-1}\right)$ and three rates of $B\left(0,1.5 \& 3 \mathrm{~kg} \mathrm{ha}^{-1}\right)$. The field trial was laid out in a randomized complete block design with three replications. The layout was made for the first crop and kept undisturbed for the second crop. Zinc as $\mathrm{ZnSO}_{4} .7 \mathrm{H}_{2} \mathrm{O}$ and boron as $\mathrm{H}_{3} \mathrm{BO}_{3}$ were applied to the first crop (onion) only. Every plot received an equal amount of some macronutrients, the rates being $80 \mathrm{~kg} \mathrm{~N} \mathrm{ha}^{-1}, 30 \mathrm{~kg} \mathrm{P} \mathrm{ha}^{-1}, 100 \mathrm{~kg} \mathrm{~K} \mathrm{ha}^{-1}$ and $25 \mathrm{~kg} \mathrm{~S}$ $\mathrm{ha}^{-1}$ for onion and $20 \mathrm{~kg} \mathrm{~N} \mathrm{ha}^{-1}, 15 \mathrm{~kg} \mathrm{P} \mathrm{ha}^{-1}$ and $20 \mathrm{~kg}$ $\mathrm{K} \mathrm{ha}^{-1}$ for mungbean. All fertilizers except urea were incorporated to soil during final land preparation. Urea was applied in three equal splits, the first split during final land preparation, the second and the third splits at growth stages, with 20-25 days' intervals. Mungbean (cv. BINA Mung 8) was grown on the same plots after harvesting of onion. Intercultural operations e.g. weeding, irrigation, etc. were done as usual to support normal crop growth. Plot-wise yield and yield components were recorded. Bulb samples from every plot were chemically analyzed for $\mathrm{P}, \mathrm{K}, \mathrm{S}$ and $\mathrm{B}$ contents following standard methods (Chapman and Pratt, 1964; Yoshida et al., 1976). Data were statistically analyzed following F-test and the mean comparisons were made by DMRT (Duncan's Multiple Range Test) at 5\% level of significance.

\section{Results and Discussion}

A significant effect of $\mathrm{Zn}$ and B was observed on the first crop (onion) and their residual effect was also significant on the second crop (mungbean). This study indicates that application of $\mathrm{Zn}$ and $\mathrm{B}$ is required for achieving higher bulb yield of onion and seed yield of mungbean. The results are discussed under two crop headings.

\section{Effects of Zn and B on onion}

Plant height: Plant height was measured at 65 days after planting. There was a significant effect of Zn-B treatments on the plant height of the crop (Table 1). The $\mathrm{T}_{9}\left(\mathrm{Zn}_{4} \mathrm{~B}_{3}\right)$ treatment produced the tallest plants $(34.0 \mathrm{~cm})$ which did not differ significantly from $T_{8}$ treatment $\left(\mathrm{Zn}_{4} \mathrm{~B}_{1.5}\right)$ showing $33.7 \mathrm{~cm}$ height plants. The control treatment $\left(\mathrm{Zn}_{0} \mathrm{~B}_{0}\right)$ caused the shortest plants $(31.4 \mathrm{~cm})$. Similarly, Abedin et al. (2012) observed that plant parameters including plant height were the maximum when $\mathrm{Zn}$ and $\mathrm{B}$ were applied.

Bulb length: The length of bulb measured after harvest was significantly affected by the different treatments. Like plant height, the highest bulb length $(1.32 \mathrm{~cm})$ was observed with the $\mathrm{T}_{9}$ treatment $\left(\mathrm{Zn}_{4} \mathrm{~B}_{3}\right)$ while the lowest length $(1.12 \mathrm{~cm})$ was recorded in the $T_{1}$ treatment where $\mathrm{Zn}$ or $\mathrm{B}$ was not 
applied (Table 1). Treatment $\mathrm{T}_{9}\left(\mathrm{Zn}_{4} \mathrm{~B}_{3}\right)$ differed significantly with all other treatments except $\mathrm{T}_{8}$ $\left(\mathrm{Zn}_{4} \mathrm{~B}_{1.5}\right)$. The bulb length due to $\mathrm{T}_{8}$ treatment was statistically similar to that due to $\mathrm{T}_{3}\left(\mathrm{Zn}_{0} \mathrm{~B}_{3}\right), \mathrm{T}_{6}$ $\left(\mathrm{Zn}_{2} \mathrm{~B}_{3}\right)$ and $\mathrm{T}_{7}\left(\mathrm{Zn}_{4} \mathrm{~B}_{0}\right)$ treatments.

Bulb diameter: The highest bulb diameter $(3.5 \mathrm{~cm})$ was observed in the $\mathrm{T}_{9}$ treatment $\left(\mathrm{Zn}_{4} \mathrm{~B}_{3}\right)$ and that was significantly different from all other treatments (Table 1$)$. The lowest bulb diameter $(2.8 \mathrm{~cm})$ was recorded in the $\mathrm{T}_{1}$ treatment (control) and statistically similar result was observed by the $\mathrm{T}_{4} \quad\left(\mathrm{Zn}_{2} \mathrm{~B}_{0}\right)$ treatment. This result indicates a greater effect of $\mathrm{B}$ supplement over $\mathrm{Zn}$ supplement which in turn influenced the bulb yield.

Bulb yield: Crop yield was the most important parameter in this study. Bulb yield varied from $8.5 \mathrm{t}$ $\mathrm{ha}^{-1}$ recorded in $\mathrm{Zn}_{0} \mathrm{~B}$ (control) to $12.3 \mathrm{t} \mathrm{ha}^{-1}$ noted in $\mathrm{Zn}_{4} \mathrm{~B}_{3}$ treatment (Table 1). All the treatments $\left(\mathrm{T}_{2}-\mathrm{T}_{9}\right)$ showed significantly higher bulb yield over the control $\left(\mathrm{T}_{1}\right)$. The highest yield due to $\mathrm{Zn}_{4} \mathrm{~B}_{3}$ treatment was 51.9\% higher over control (Fig.1). When the results of $\mathrm{Zn}$ and $\mathrm{B}$ effect are carefully looked into, it appears that the effect of B application was dominant over that of Zn. Alam et al. (2010) found that combined application of $\mathrm{Zn}$ and $\mathrm{B}$ increased the bulb yield by $49.7 \%$ over no application of $\mathrm{Zn}$ and $\mathrm{B}$.

The significant effect of $\mathrm{Zn}$ and B treatments can be related to soil test values that the experimental field had low level of Zn (0.63 $\left.\mu \mathrm{g} \mathrm{g}^{-1}\right)$ and B (0.27 $\left.\mu \mathrm{g} \mathrm{g}^{-1}\right)$. As outlined in FRG-2012, the critical limit (C.L.) of DTPA extractable soil $\mathrm{Zn}$ is $0.60 \mathrm{mg} \mathrm{kg}^{-1}$ and that of hot water extractable soil B is $0.20 \mathrm{mg} \mathrm{kg}^{-1}$ and crop response to added nutrient is expected when the soil status of that nutrient lies within $225 \%$ of the C. L.

Nutrient concentration: We measured the phosphorus (P), potassium (K), sulphur (S) and boron (B) concentrations in bulb. The $\mathrm{P}$ concentration in bulb ranged from $0.162 \%$ to $0.188 \%$ (Table 2). The highest $\mathrm{P}$ concentration was recorded in $\mathrm{T}_{4}\left(\mathrm{Zn}_{2} \mathrm{~B}_{0}\right)$ treatment which was statistically similar to $T_{7}$ $\left(\mathrm{Zn}_{4} \mathrm{~B}_{0}\right), \mathrm{T}_{8}\left(\mathrm{Zn}_{4} \mathrm{~B}_{1.5}\right)$ and $\mathrm{T}_{9}\left(\mathrm{Zn}_{4} \mathrm{~B}_{3}\right)$ treatments. The lowest $\mathrm{P}$ concentration was observed in $\mathrm{T}_{6}$ treatment $\left(\mathrm{Zn}_{2} \mathrm{~B}_{3}\right)$ which was statistically similar to $\mathrm{T}_{3}\left(\mathrm{Zn}_{0} \mathrm{~B}_{3}\right)$ and $\mathrm{T}_{5}\left(\mathrm{Zn}_{2} \mathrm{~B}_{1.5}\right)$ treatments. The highest $\mathrm{K}$ concentration was observed as $0.705 \%$ in $\mathrm{T}_{7}$ treatment $\left(\mathrm{Zn}_{4} \mathrm{~B}_{0}\right)$ which was not significantly different from other treatments, except $T_{3}\left(Z_{0} B_{3}\right)$.

Table 1. Effects of Zn and B on plant height, bulb length, buld diameter and bulb yield of onion

\begin{tabular}{|l|c|c|c|c|}
\hline Treatments & $\begin{array}{c}\text { Plant height } \\
(\mathbf{c m})\end{array}$ & $\begin{array}{c}\text { Bulb length } \\
\mathbf{( c m )}\end{array}$ & $\begin{array}{c}\text { Bulb diameter } \\
\mathbf{( c m )}\end{array}$ & $\begin{array}{c}\text { Bulb yield } \\
\text { (t ha } \mathbf{- 1} \text { on fresh wt. basis) }\end{array}$ \\
\hline $\mathrm{T}_{1}: \mathrm{Zn}_{0} \mathrm{~B}_{0}$ & $31.4 \mathrm{e}$ & $1.12 \mathrm{e}$ & $2.80 \mathrm{e}$ & 8.1c \\
\hline $\mathrm{T}_{2}: \mathrm{Zn}_{0} \mathrm{~B}_{1.5}$ & $31.7 \mathrm{de}$ & $1.15 \mathrm{de}$ & $3.05 \mathrm{~cd}$ & $10.6 \mathrm{ab}$ \\
\hline $\mathrm{T}_{3}: \mathrm{Zn}_{0} \mathrm{~B}_{3}$ & $32.6 \mathrm{~b}$ & $1.22 \mathrm{bc}$ & $3.15 \mathrm{bc}$ & $12.0 \mathrm{a}$ \\
\hline $\mathrm{T}_{4}: \mathrm{Zn}_{2} \mathrm{~B}_{0}$ & $31.6 \mathrm{de}$ & $1.15 \mathrm{de}$ & $2.90 \mathrm{de}$ & $11.1 \mathrm{ab}$ \\
\hline $\mathrm{T}_{5}: \mathrm{Zn}_{2} \mathrm{~B}_{1.5}$ & $32.2 \mathrm{c}$ & $1.19 \mathrm{~cd}$ & $3.10 \mathrm{bc}$ & $11.4 \mathrm{ab}$ \\
\hline $\mathrm{T}_{6}: \mathrm{Zn}_{2} \mathrm{~B}_{3}$ & $33.0 \mathrm{~b}$ & $1.23 \mathrm{bc}$ & $3.25 \mathrm{~b}$ & $10.3 \mathrm{~b}$ \\
\hline $\mathrm{T}_{7}: \mathrm{Zn}_{4} \mathrm{~B}_{0}$ & $32.0 \mathrm{~cd}$ & $1.23 \mathrm{bc}$ & $2.99 \mathrm{~cd}$ & $11.5 \mathrm{ab}$ \\
\hline $\mathrm{T}_{8}: \mathrm{Zn}_{4} \mathrm{~B}_{1.5}$ & $33.7 \mathrm{a}$ & $1.27 \mathrm{ab}$ & $3.15 \mathrm{bc}$ & $12.3 \mathrm{a}$ \\
\hline $\mathrm{T}_{9}: \mathrm{Zn}_{4} \mathrm{~B}_{3}$ & $34.0 \mathrm{a}$ & $1.32 \mathrm{a}$ & $3.50 \mathrm{a}$ & 0.26 \\
\hline $\mathrm{SE}( \pm)$ & 0.15 & 0.01 & 0.03 & 14.7 \\
\hline $\mathrm{CV}(\%)$ & 2.83 & 5.67 & 6.71 & \\
\hline
\end{tabular}

In a column, the figures having same letter do not differ significantly at $5 \%$ level.

$\mathrm{CV}=$ Co-efficient of variation, $\mathrm{SE}=$ Standard error of means

The lowest K concentration of bulb was recorded as $0.605 \%$ in $\mathrm{T}_{3}\left(\mathrm{Zn}_{0} \mathrm{~B}_{3}\right)$ treatment which was significantly different from all other treatments, except $\mathrm{T}_{7}\left(\mathrm{Zn}_{4} \mathrm{~B}_{0}\right)$. The $\mathrm{S}$ concentration of bulb 
varied from $0.224 \%$ to $0.298 \%$ over the treatments. The highest $S$ content in bulb was observed in $T_{8}$ treatment $\left(\mathrm{Zn}_{4} \mathrm{~B}_{1.5}\right)$ which was significant over all other treatments except $T_{2}, T_{3}, T_{4}$ and $T_{9}$. The lowest $\mathrm{S}$ content was noted in control treatment which was statistically similar to $T_{5}, T_{6}$ and $T_{7}$ treatments (Table 2). Boron concentration of bulb was the highest $\left(85 \mu \mathrm{g} \mathrm{g}^{-1}\right)$ due to $\mathrm{T}_{3}\left(\mathrm{Zn}_{0} \mathrm{~B}_{3}\right)$ treatment and the lowest $\left(44 \mu \mathrm{g} \mathrm{g}^{-1}\right)$ for $\mathrm{T}_{1}$ treatment $\left(\mathrm{Zn}_{0} \mathrm{~B}_{0}\right)$. The highest $\mathrm{B}$ concentration recorded by the $\mathrm{T}_{3}$ treatment was statistically similar to that measured with the $T_{8}$ $\left(\mathrm{Zn}_{4} \mathrm{~B}_{1.5}\right)$ and $\mathrm{T}_{9}\left(\mathrm{Zn}_{4} \mathrm{~B}_{3}\right)$ treatments. The control treatment $\left(\mathrm{Zn}_{0} \mathrm{~B}_{0}\right)$ was also statistically similar to $\mathrm{T}_{4}$ $\left(\mathrm{Zn}_{2} \mathrm{~B}_{0}\right)$ and $\mathrm{T}_{7}\left(\mathrm{Zn}_{4} \mathrm{~B}_{0}\right)$ treatments which result otherwise indicates that $\mathrm{B}$ supplement enhanced the B concentration of bulb. The critical level of boron in crops ranges from 5 to $10 \mu \mathrm{g} \mathrm{g}^{-1}$ for monocots and 20 to $70 \mu \mathrm{g} \mathrm{g}^{-1}$ for dicots (Mortvedt, 1991).

Table 2. Effects of $\mathrm{Zn}$ and B application on $\mathrm{P}, \mathrm{K}, \mathrm{S}$ and B concentrations of onion bulb

\begin{tabular}{|c|c|c|c|c|}
\hline Treatments & P conc. (\%) & K conc. (\%) & S conc. (\%) & B conc. $\left(\mu g g^{-1}\right)$ \\
\hline $\mathrm{T}_{1}: \mathrm{Zn}_{0} \mathrm{~B}_{0}$ & $0.167 \mathrm{abc}$ & 0.680ab & $0.244 \mathrm{bc}$ & $44 d$ \\
\hline $\mathrm{T}_{2}: \mathrm{Zn}_{0} \mathrm{~B}_{1.5}$ & $0.183 a b$ & $0.680 \mathrm{ab}$ & $0.279 a b$ & $68 \mathrm{bc}$ \\
\hline $\mathrm{T}_{3}: \mathrm{Zn}_{0} \mathrm{~B}_{3}$ & $0.170 \mathrm{bc}$ & $0.605 \mathrm{~b}$ & $0.277 \mathrm{ab}$ & $85 a$ \\
\hline $\mathrm{T}_{4}: \mathrm{Zn}_{2} \mathrm{~B}_{0}$ & $0.188 a$ & $0.655 \mathrm{ab}$ & $0.275 \mathrm{ab}$ & $45 \mathrm{~d}$ \\
\hline $\mathrm{T}_{5}: \mathrm{Zn}_{2} \mathrm{~B}_{1.5}$ & $0.168 \mathrm{bc}$ & $0.630 \mathrm{ab}$ & $0.248 \mathrm{bc}$ & $58 \mathrm{c}$ \\
\hline $\mathrm{T}_{6}: \mathrm{Zn}_{2} \mathrm{~B}_{3}$ & $0.162 \mathrm{bc}$ & $0.630 \mathrm{ab}$ & $0.224 \mathrm{c}$ & $59 \mathrm{c}$ \\
\hline $\mathrm{T}_{7}: \mathrm{Zn}_{4} \mathrm{~B}_{0}$ & $0.184 a$ & $0.705 a$ & $0.255 b c$ & $47 d$ \\
\hline $\mathrm{T}_{8}: \mathrm{Zn}_{4} \mathrm{~B}_{1.5}$ & $0.186 a$ & $0.680 \mathrm{ab}$ & $0.298 \mathrm{a}$ & 71abc \\
\hline $\mathrm{T}_{9}: \mathrm{Zn}_{4} \mathrm{~B}_{3}$ & $0.175 a$ & $0.680 \mathrm{ab}$ & $0.272 \mathrm{ab}$ & 82ab \\
\hline SE ( $( \pm)$ & 0.002 & 0.008 & 0.005 & 0.03 \\
\hline CV (\%) & 6.35 & 7.19 & 10.73 & 4.44 \\
\hline
\end{tabular}

In a column, the figures having same letter do not differ significantly at $5 \%$ level.

$\mathrm{CV}=$ Co-efficient of variation, $\mathrm{SE}=$ Standard error of means

Nutrient uptake: Uptake of P, K, S and B by bulb was calculated from yield and nutrient concentration data as presented in Table 3. The P uptake ranged from 3.26 - $5.19 \mathrm{~kg} \mathrm{ha}^{-1}$ across the treatments. The highest $\mathrm{P}$ uptake was recorded by the $\mathrm{T}_{9}$ treatment $\left(\mathrm{Zn}_{4} \mathrm{~B}_{3}\right)$ which was statistically similar to all other treatments except $T_{1}, T_{4}$ and $T_{6}$. The lowest $P$ uptake was observed in control treatment $\left(\mathrm{Zn}_{0} \mathrm{~B}_{0}\right)$ which was statistically different from all other treatments. The K uptake by onion bulb varied between $13.29 \mathrm{~kg}$ $\mathrm{ha}^{-1}$ and $20.12 \mathrm{~kg} \mathrm{ha}^{-1}$ over the treatments, the highest $\mathrm{K}$ uptake being noted with $\mathrm{T}_{9}$ treatment $\left(\mathrm{Zn}_{4} \mathrm{~B}_{3}\right)$ and the lowest $\mathrm{K}$ uptake observed with control treatment $\left(\mathrm{Zn}_{0} \mathrm{~B}_{0}\right)$. The $\mathrm{T}_{9}$ treatment showing the highest $\mathrm{K}$ uptake was statistically similar to all other treatments except $\mathrm{T}_{1}\left(\mathrm{Zn}_{0} \mathrm{~B}_{0}\right), \mathrm{T}_{4}\left(\mathrm{Zn}_{2} \mathrm{~B}_{0}\right)$ and $\mathrm{T}_{5}\left(\mathrm{Zn}_{2} \mathrm{~B}_{1.5}\right)$.
For the $\mathrm{S}$ uptake by bulb, the highest result $(8.27 \mathrm{~kg}$ $\left.h^{-1}\right)$ was observed with $T_{8}$ treatment $\left(Z_{4} B_{1.5}\right)$ which was statistically similar to $T_{9}, T_{2}$ and $T_{3}$ treatments (Table 3). The lowest $\mathrm{S}$ uptake by bulb (4.27 kg ha ${ }^{-1}$ ) was observed in $\mathrm{T}_{1}$ treatment that received no $\mathrm{Zn}$ and $\mathrm{B}$ (control) application which was statistically different from all other treatments. Boron uptake by bulb was found to vary from 85.8 to $246.1 \mathrm{~g} \mathrm{ha}^{-1}$ across the treatments. The highest $\mathrm{B}$ uptake by bulb was due to $T_{9}$ treatment $\left(\mathrm{Zn}_{4} \mathrm{~B}_{3}\right)$ which was statistically different from all treatments except $T_{3}\left(Z_{0} B_{3}\right)$. The lowest $B$ uptake was found in $\mathrm{T}_{1}$ treatment $\left(\mathrm{Zn}_{0} \mathrm{~B}_{0}\right)$ that received no $\mathrm{B}$ and $\mathrm{Zn}$ application. This can be related to initial status of soil $\mathrm{Zn}$ and $\mathrm{B}$ which showed deficient status. 
Table 3. Effects of Zn and B application on P, K, S and B uptake by onion

\begin{tabular}{|l|l|l|l|l|}
\hline Treatments & $\mathbf{P}\left(\mathbf{k g ~ h a}^{\mathbf{- 1}}\right)$ & $\left.\mathbf{K} \mathbf{~ k g ~ h a}^{\mathbf{- 1}}\right)$ & $\left.\mathbf{S} \mathbf{( k g ~ h a}^{\mathbf{- 1}}\right)$ & $\mathbf{B} \mathbf{g ~ h a}^{\mathbf{- 1}} \mathbf{)}$ \\
\hline $\mathrm{T}_{1}: \mathrm{Zn}_{0} \mathrm{~B}_{0}$ & $3.26 \mathrm{bc}$ & $13.29 \mathrm{c}$ & $4.77 \mathrm{c}$ & $85.8 \mathrm{e}$ \\
\hline $\mathrm{T}_{2}: \mathrm{Zn}_{0} \mathrm{~B}_{1.5}$ & $4.68 \mathrm{a}$ & $17.39 \mathrm{ab}$ & $7.13 \mathrm{ab}$ & $173.9 \mathrm{bc}$ \\
\hline $\mathrm{T}_{3}: \mathrm{Zn}_{0} \mathrm{~B}_{3}$ & $4.92 \mathrm{ab}$ & $17.52 \mathrm{ab}$ & $8.02 \mathrm{a}$ & $243.3 \mathrm{a}$ \\
\hline $\mathrm{T}_{4}: \mathrm{Zn}_{2} \mathrm{~B}_{0}$ & $4.26 \mathrm{~b}$ & $14.85 \mathrm{bc}$ & $6.24 \mathrm{~b}$ & $102.1 \mathrm{~d}$ \\
\hline $\mathrm{T}_{5}: \mathrm{Zn}_{2} \mathrm{~B}_{1.5}$ & $4.50 \mathrm{a}$ & $16.87 \mathrm{~b}$ & $6.64 \mathrm{~b}$ & $155.3 \mathrm{c}$ \\
\hline $\mathrm{T}_{6}: \mathrm{Zn}_{2} \mathrm{~B}_{3}$ & $4.45 \mathrm{~b}$ & $17.33 \mathrm{ab}$ & $6.16 \mathrm{~b}$ & $162.3 \mathrm{c}$ \\
\hline $\mathrm{T}_{7}: \mathrm{Zn}_{4} \mathrm{~B}_{0}$ & $4.57 \mathrm{a}$ & $17.52 \mathrm{ab}$ & $6.34 \mathrm{~b}$ & $116.8 \mathrm{~d}$ \\
\hline $\mathrm{T}_{8}: \mathrm{Zn}_{4} \mathrm{~B}_{1.5}$ & $5.16 \mathrm{a}$ & $18.87 \mathrm{a}$ & $8.27 \mathrm{a}$ & $197.0 \mathrm{~b}$ \\
\hline $\mathrm{T}_{9}: \mathrm{Zn}_{4} \mathrm{~B}_{3}$ & $5.19 \mathrm{a}$ & $20.12 \mathrm{a}$ & $8.07 \mathrm{a}$ & $246.1 \mathrm{a}$ \\
\hline $\mathrm{SE}( \pm)$ & 0.0013 & 0.005 & 0.0032 & 0.0019 \\
\hline $\mathrm{CV}(\%)$ & 2.40 & 2.60 & 3.25 & 36.33 \\
\hline
\end{tabular}

In a column, the figures having same letter do not differ significantly at $5 \%$ level.

$\mathrm{CV}=$ Co-efficient of variation; $\mathrm{SE}=$ Standard error of means

\section{Effects of Zn and B application on mungbean}

Plant height: The tallest plants were observed in $\mathrm{Zn}_{4} \mathrm{~B}_{3}$-treated plots $\left(\mathrm{T}_{9}\right)$ which was significantly different from all other treatments (Table 4). The shortest plants were noted in $\mathrm{T}_{1}$ treatment $\left(\mathrm{Zn}_{0} \mathrm{~B}_{0}\right)$. Next to $T_{9}$, the $T_{6}$ treatment $\left(Z_{2} B_{3}\right)$ followed by $T_{7}$ $\left(\mathrm{Zn}_{4} \mathrm{~B}_{0}\right)$ and $\mathrm{T}_{8}\left(\mathrm{Zn}_{4} \mathrm{~B}_{1.5}\right)$ treatments showed higher plant height.

Pod length: Pod length ranged from $7.5-8.9 \mathrm{~cm}$ over the treatments (Table 4). Like other parameters, $\mathrm{T}_{9}$ treatment $\left(\mathrm{Zn}_{4} \mathrm{~B}_{3}\right)$ exhibited the biggest pod size which was statistically superior to all other treatments. The smallest sized pods were noted in $T_{1}$ treatment (control) which however was statistically similar with $\mathrm{T}_{2}\left(\mathrm{Zn}_{0} \mathrm{~B}_{1.5}\right), \mathrm{T}_{3}\left(\mathrm{Zn}_{0} \mathrm{~B}_{3}\right)$ and $\mathrm{T}_{4}$ $\left(\mathrm{Zn}_{2} \mathrm{~B}_{0}\right)$ treatments.

Number of pods plant ${ }^{-1}$ : Per plant pods ranged from 8 to 11 over the Zn-B treatments. The highest number of pods plant ${ }^{-1}$ was recorded by the $T_{9}$ treatment $\left(\mathrm{Zn}_{4} \mathrm{~B}_{3}\right)$ which was statistically similar to $\mathrm{T}_{6} \quad\left(\mathrm{Zn}_{2} \mathrm{~B}_{3}\right), \quad \mathrm{T}_{3} \quad\left(\mathrm{Zn}_{0} \mathrm{~B}_{3}\right)$ and $\mathrm{T}_{8} \quad\left(\mathrm{Zn}_{4} \mathrm{~B}_{1.5}\right)$ treatments. Except $T_{2}, T_{4}, T_{5}$ and $T_{7}$ all other treatments produced significantly higher number of pods plant ${ }^{-1}$ over control.

Thousand seed weight: Thousand seed weight was the maximum as $38.4 \mathrm{~g}$ and the minimum as $36.2 \mathrm{~g}$ over the treatments (Table 4). The highest 1000-seed weight was observed with $T_{6}\left(Z_{2} B_{3}\right)$ treatment which was statistically significant over all other treatments. The minimum 1000-seed weight was found in $T_{1}$ treatment which was only comparable with $\mathrm{T}_{6}\left(\mathrm{Zn}_{2} \mathrm{~B}_{3}\right)$ treatment.

Seed yield: There was a significant residual effect of the $\mathrm{Zn}-\mathrm{B}$ treatments on the seed yield of mungbean (Table 4). The $\mathrm{T}_{9}$ treatment $\left(\mathrm{Zn}_{4} \mathrm{~B}_{3}\right)$ produced the maximum seed yield (853.5 $\left.\mathrm{kg} \mathrm{ha}^{-1}\right)$ and the control treatment $\left(\mathrm{Zn}_{0} \mathrm{~B}_{0}\right)$ did the minimum yield $(429.4 \mathrm{~kg}$ $\left.h a^{-1}\right)$. The highest seed yield recorded by the $\mathrm{T}_{9}$ treatment was comparable to that recorded by the $\mathrm{T}_{6}$ treatment $\left(\mathrm{Zn}_{2} \mathrm{~B}_{3}\right)$. The control yield was statistically similar to that recorded with the $\mathrm{T}_{4}$ treatment $\left(\mathrm{Zn}_{2} \mathrm{~B}_{0}\right)$ indicating that seed yield was more influenced by $\mathrm{B}$ than by $\mathrm{Zn}$ addition. The yield increased by $02-99 \%$ due to residual effect of $\mathrm{Zn}$ and B application (Fig. 1). Hossain et al. (2008) from a 3year field experiment with maize-mungbean-rice in calcareous soil of Jessore (AEZ 11) have reported 2 $\mathrm{kg} \mathrm{Zn} \mathrm{ha}{ }^{-1}$ as the optimum rate of $\mathrm{Zn}$ for both maize and rice, and reduction of $\mathrm{Zn}$ rate by $1 \mathrm{~kg} \mathrm{ha}^{-1}$ is possible for rice when mungbean residue is incorporated into the plot before transplanting of $\mathrm{T}$. Aman rice. Boron application at $1.5 \mathrm{~kg} \mathrm{ha}^{-1}$ to the first crop can meet up their requirement for the subsequent crops in a pattern (Khanom, 2013; Jahiruddin and Islam, 2014). 
Table 4. Residual effects of $\mathrm{Zn}$ and B application on the growth, yield and yield components of mungbean

\begin{tabular}{|l|c|c|c|c|c|}
\hline Treatments & $\begin{array}{c}\text { Plant height } \\
(\mathbf{c m})\end{array}$ & $\begin{array}{c}\text { Pod length } \\
(\mathbf{c m})\end{array}$ & $\begin{array}{c}\text { Pods plant } \\
(\mathbf{N o .})\end{array}$ & $\begin{array}{c}\text { 1000-seed } \\
\text { weight }(\mathbf{g})\end{array}$ & $\begin{array}{c}\text { Seed yield } \\
\left(\mathbf{k g ~ h a}^{-1} \mathbf{)}\right.\end{array}$ \\
\hline $\mathrm{T}_{1}: \mathrm{Zn}_{0} \mathrm{~B}_{0}$ & $32.3^{\mathrm{f}}$ & $7.5^{\mathrm{e}}$ & $8^{\mathrm{c}}$ & $36.2^{\mathrm{b}}$ & $429.4^{\mathrm{e}}$ \\
\hline $\mathrm{T}_{2}: \mathrm{Zn}_{0} \mathrm{~B}_{1.5}$ & $36.3^{\mathrm{d}}$ & $7.7^{\mathrm{de}}$ & $9^{\mathrm{bc}}$ & $36.8^{\mathrm{b}}$ & $623.4^{\mathrm{d}}$ \\
\hline $\mathrm{T}_{3}: \mathrm{Zn}_{0} \mathrm{~B}_{3}$ & $36.5^{\mathrm{cd}}$ & $7.9^{\mathrm{cde}}$ & $10^{\mathrm{ab}}$ & $37.0^{\mathrm{b}}$ & $777.9^{\mathrm{b}}$ \\
\hline $\mathrm{T}_{4}: \mathrm{Zn}_{2} \mathrm{~B}_{0}$ & $33.5^{\mathrm{e}}$ & $7.9^{\mathrm{b}-\mathrm{e}}$ & $8^{\mathrm{c}}$ & $36.4^{\mathrm{b}}$ & $439.3^{\mathrm{e}}$ \\
\hline $\mathrm{T}_{5}: \mathrm{Zn}_{2} \mathrm{~B}_{1.5}$ & $36.5^{\mathrm{cd}}$ & $8.1^{\mathrm{bc}}$ & $9^{\mathrm{bc}}$ & $36.5^{\mathrm{b}}$ & $629.1^{\mathrm{d}}$ \\
\hline $\mathrm{T}_{6}: \mathrm{Zn}_{2} \mathrm{~B}_{3}$ & $37.5^{\mathrm{b}}$ & $8.4^{\mathrm{b}}$ & $11^{\mathrm{a}}$ & $38.4^{\mathrm{a}}$ & $806.0^{\mathrm{ab}}$ \\
\hline $\mathrm{T}_{7}: \mathrm{Zn}_{4} \mathrm{~B}_{0}$ & $37.3^{\mathrm{bc}}$ & $8.0^{\mathrm{bcd}}$ & $9^{\mathrm{bc}}$ & $36.7^{\mathrm{b}}$ & $671.7^{\mathrm{cd}}$ \\
\hline $\mathrm{T}_{8}: \mathrm{Zn}_{4} \mathrm{~B}_{1.5}$ & $36.6^{\mathrm{bcd}}$ & $8.3^{\mathrm{bc}}$ & $10^{\mathrm{ab}}$ & $36.5^{\mathrm{b}}$ & $698.4^{\mathrm{c}}$ \\
\hline $\mathrm{T}_{9}: \mathrm{Zn}_{4} \mathrm{~B}_{3}$ & $40.1^{\mathrm{a}}$ & $8.9^{\mathrm{a}}$ & $11^{\mathrm{a}}$ & $36.8^{\mathrm{b}}$ & $853.5^{\mathrm{a}}$ \\
\hline $\mathrm{SE}( \pm)$ & 0.35 & 0.07 & 0.22 & 0.12 & 23.36 \\
\hline $\mathrm{CV}(\%)$ & 6.07 & 5.57 & 14.49 & 1.98 & 13.55 \\
\hline
\end{tabular}

In a column, the figures having same letter do not differ significantly at $5 \%$ level.

$\mathrm{CV}=$ Co-efficient of variation; $\mathrm{SE}=$ Standard error of means

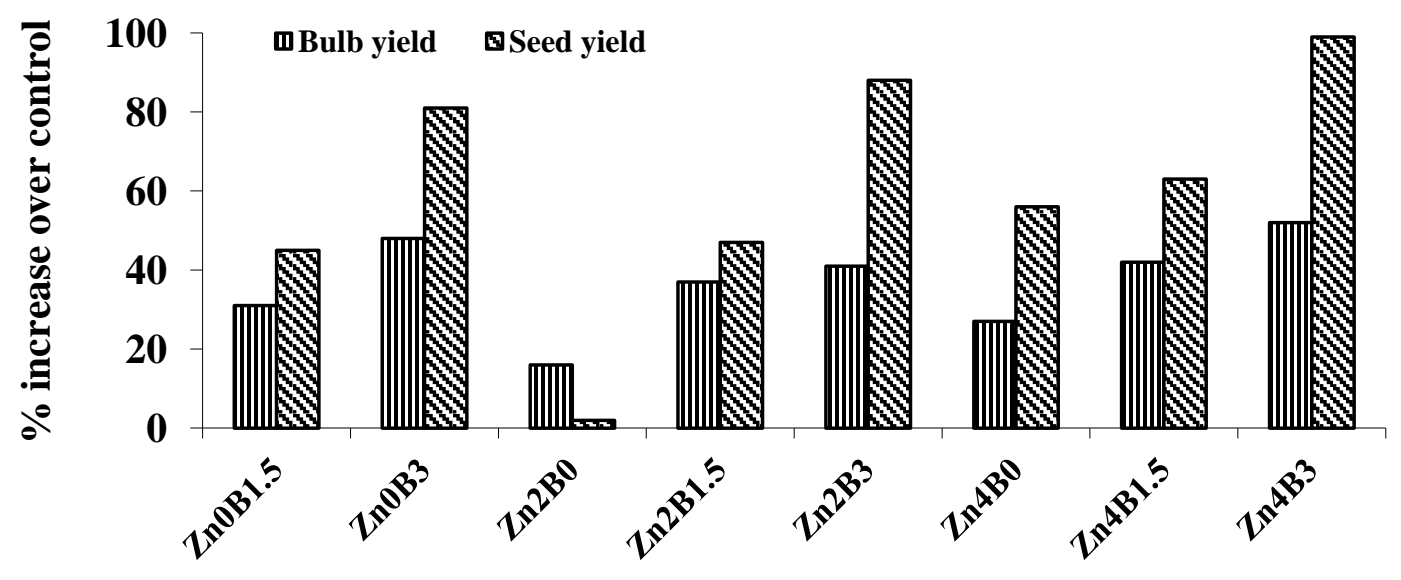

Treatments

Figure 1. Percent yield increase due to Zn-B treatments over control

\section{Conclusions}

Application of $\mathrm{Zn}$ and $\mathrm{B}$ had significant positive effect on onion and its residual effect on mungbean in respect of crop growth, yield and nutrient uptake. Addition of $\mathrm{Zn}$ at $4 \mathrm{~kg} \mathrm{ha}^{-1}$ along with $\mathrm{B}$ at $3 \mathrm{~kg} \mathrm{ha}^{-1}$ was found as the best treatment. Effect of $B$ on the growth and yield of crops was more prominent than that of $\mathrm{Zn}$.

\section{Acknowledgement}

This work was supported by the Coordinated SubProject on Soil Fertility and Fertilizer Management for Crops and Cropping Patterns under the National Agricultural Technology Project (NATP) Phase-1, Bangladesh Agricultural Research Council (BARC), Dhaka. 


\section{References}

Abedin MJ, Nurul M, Alam M, Hossain J, Ara N A, Haque KMF (2012). Effect of micronutrients on growth and yield of onion under calcareous soil environment. International Journal of Biosciences, 2 (8): 95-101.

Ahmed M, Jahiruddin M, Mian MH (2007). Screening of wheat genotypes for boron efficiency. Journal of Plant Nutrition, 30: 1127-1138.

Alam MN, Abedin J, Azad MAK (2010). Effect of micronutrients on growth and yield of onion under calcareous soil environment. International Research Journal of Plant Science, 1 (3) 056-061.

Cakmak I, Torun B, Erenoglu B, Kalayci M, Yilmaz A, Ekij H, Braun HJ (1996). Zinc deficiency in soils and plants in Turkey and plant mechanism involved in zinc deficiency. Turkish Journal of Agriculture and Forestry, 20: 13-23.

Chapman CA, Pratt PF (1964). Methods of Analysis for Soil, Plant and Water. Div. Agric. Sci., University of California, USA.

Hossain MA, Jahiruddin M, Islam MR, Mian MH (2008). The requirement of zinc for improvement of crop yield and mineral nutrition in the maize-mungbean-rice system. Plant and Soil, 306: 13-22.
Jahiruddin M (2011). Screening, selection and Molecular Characterization of Boron Efficient Wheat Genotypes. Project Completion Report., Dept. of Soil Science, BAU, Mymensingh.

Jahiruddin M, Islam MR (2014). Project Report (2011-2014). Requirement of Micronutrients for Crops and Cropping Patterns. PIU-BARC (NATP Phase-I) project. Project ID No. 339.

Jahiruddin M, Hoque MS, Haque AKMM, Roy PK (1992). Influence of boron, copper, and molybdenun on grain formation in wheat. Crop Research, 5: 35-42.

Khanom R (2013). Requirement of zinc and Boron for Composite and Hybrid Maize and Their Residual Effects on Rice. Ph.D. Dissertation. Dept. of Soil Science, BAU, Mymensingh.

Metwally A, El-Shazoly R, Hamada AM (2012). Effect of boron on growth criteria of some wheat cultivars. Journal of Biology and Earth Science, 2:1-9.

Mortvedt JJ (1991). Micronutrient fertilizer technology. In: J. J. Mortvedt, F. R. Cox, L.M. Shuman and R.M. Welch (Eds.), Micronutrients in Agriculture. Soil Sci. Soc. Amer., Mad., WI, pp. 523-548.

Yoshida S, Fomo AD, Cock JA, Gomez KA (1976). Physiological Studies of Rice. International Rice Research Institute ,Manila, Philippines. 